ZOOLOGIA 27 (2): 228-244, April, 2010

doi: $10.1590 /$ S1984-46702010000200011

\title{
Foregut morphology of Pseudothelphusidae and Trichodactylidae (Decapoda: Brachyura) from northeastern Pará, Brazil
}

\author{
Soraya Tatiana M. Alves; Fernando A. Abrunhosa \& Jô de F. Lima
}

\begin{abstract}
Laboratório de Carcinologia, Instituto de Estudos Costeiros, Campus Universitário de Bragança, Universidade Federal do Pará. Alameda Leandro Ribeiro, Aldeia, 68600-000 Bragança, Pará, Brazil. E-mail: faraujo@ufpa.br
\end{abstract}

\begin{abstract}
The gross morphology of foregut was investigated and described in detail for four freshwater crab species: a pseudothelphusid, Fredius reflexifrons (Ortmann, 1897) and three trichodactylids - Sylviocarcinus pictus (H. MilneEdwards, 1853), Valdivia serrata White, 1847, and Dilocarcinus septemdentatus (Herbst, 1783). In general, the gastric mills of freshwater crabs showed a similar degree of complexity in relation to other marine species of Anomura and Brachyura previously described in the literature. However, significant morphological differences were observed among the analyzed species, as in ossicle numbers, features and connection types. A total of 38 ossicles were described for $S$. pictus and $V$. serrata and 37 ossicles for $D$. septemdentatus and $F$. reflexifrons, respectively. The latter species can be distinguished from the others by the presence of a wide cardiac sac resembling two sacs. Most of the ossicles were connected through a rigid connection, and few ossicles were fused. The degree of calcification varied little among the studied species. The differences found among the species suggest that the morphological aspects of the foregut may be useful in the identification of similar species.
\end{abstract}

KEY WORDS. Freshwater crabs; morphology; stomach; Amazon region; Neotropic.

Trichodactylidae comprises small and intermediate-sized crabs, with nearly 50 species distributed in South and Central America, occurring from southern Mexico to Argentina. According to MAGALHÃES (2003), 21 species are known in the northern region, most of which distributed in the Amazonian basin. Rare species occur in waters at altitudes above $300 \mathrm{~m}$.

Pseudothelphusidae is a diverse group of Neotropical freshwater crabs, with approximately 289 species and subspecies across 41 genera (Yeо et al. 2008). Its geographical distribution extends from northern Mexico to the southern edge of the Amazon. They are crabs of mountainous regions living in areas between altitudes of 300 to $3,000 \mathrm{~m}$, with few species occurring in the lowlands (Rodriguez 1981). In Brazil, this family is represented by five genera with twelve species, all distributed in the Amazonian basin. They are found in rivers of Guyanan and Brazilian mountains or in small shore on streams. They are not found in flooded areas (Magalhães 2003, RodRIGUez \& MagalHÃes 2005).

The morphological and functional aspects of decapod crustacean stomachs have been examined extensively in adult specimens in order to understand the correct operation of the digestive processes of each group (Meiss \& Norman 1977, KunZe \& Anderson 1979, Suthers \& Anderson 1981, Suthers 1984, Skilleter \& Anderson 1986, Mikami \& Takashima 1993, Pinn et al. 1999, Jha \& Homechaudhuri 2001, Brösing et al. 2002, Castro \& Bond-Buckup 2003). However, few investigations concentrated on the biology and ecology of freshwater species, particularly with respect to the morphology of the stomach. Such studies have relevant biological and ecological importance because they may be used as additional characteristics in the identification of groups or even of species through the description and structural comparison of foregut constituents.

In this study, the morphological features of foregut was investigated in freshwater crabs that occur in the northern state of Pará: one pseudothelphusid, Fredius reflexifrons (Ortmann, 1897) and three trichodactylids, Silviocarcinus pictus (H. Milne-Edwards, 1853), Valdivia serrata White, 1847 , and Dilocarcinus septemdentatus (Herbst, 1783).Thus, the goal of this study is to elucidate the detailed structure and characteristics of the gastric mills. The results may be used to aid in the classification of the freshwater crabs, mainly those groups that present close morphological similarities.

\section{MATERIAL AND METHODS}

This study was carried out in the Bragança region, northeastern state of Pará. Individuals were collected in the rivers Caeté, Chumucui, Guamá, and Quadipuru, all belonging to the northeastern meso-region of Pará and micro-region of Bragança city. A rectangular sieve of $0.5 \mathrm{x} 1 \mathrm{~m}$ was used in the river margins. Handicraft traps of $8 \mathrm{~cm}$ were used during sampling at night.

In the laboratory, the crabs were immersed in cold water (about $5^{\circ} \mathrm{C}$ ) before they were sacrificed. They were then conserved in alcohol 70\%+glycerol (1:1) solution. The Manual of Identification of Crustaceous Decapoda of Freshwater of Brazil (Melo 2003) was used for species identification. 
The foreguts were obtained from 10 individuals (male and females) of each species. The stomach of each individual was fixed in aqueous formalin solution (10\%) for 24 hours, immersed in hydroxide solution of potassium (10\%) and heated to $100^{\circ} \mathrm{C}$ for one hour. They were then removed and the skeletal structure of the stomach was washed in distilled water and immersed in an ethyl alcohol 70\% + glycerol (1:1) solution. Later, the foreguts were removed and transferred to another slide where they were stained with aqueous solution of Alizarinred $(0.1 \%)$ according to the methodology used by BRösING et. al. (2002) and adapted by Pilgrim (1964, 1965, 1973).

The stomach of each species was illustrated in lateral (right side), dorsal and ventral view under an optical microscope (Zeiss). The description of ossicles that compose the stomach (Tab. I), nomenclature and abbreviations followed Meiss \& Norman (1977), Martin et al. (1998) and Brösing et al. (2002).

Voucher specimens are deposited in the collection of crustaceans of the Institute National of Researches of the Amazonian - INPA (Manaus, Amazonas, Brazil) under following catalogue: D. septemdentatus: INPA 1508, S. pictus: INPA 1510, V. serrata: INPA 1511 and F. reflexifrons: INPA 1512.

\section{RESULTS}

\section{Foregut ossicles of Fredius reflexifrons}

The oesophagus is connected with antero-ventral portion of the cardiac chamber; cardiac chamber wider than long with 17 ossicles; pyloric chamber with 16 ossicles, little shorter than the cardiac chamber, terminal portion slightly straight; cardiac sac quite wide as two lateral bag.

\section{Ossicles of the gastric mill (Figs 1, 2)}

Mesocardiac ossicle (I): unpaired, moderately calcified, irregular shaped, inferior portion entirely fused to urocardiac ossicle (VII), superior portion free and subtriangular, lateral margin narrow connected to tip of pterocardiac ossicle.

Pterocardiac ossicle (II): paired, subtriangular, firmly calcified connection in the lateral margins with postpterocardiac (IIb) and mesocardiac (I) ossicles.

Postpterocardiac ossicle (IIb): paired, slightly calcified, subtriangular, with two filaments slightly calcified separated for a fine cartilaginous plate, connection with zygocardiac ossicle (V), pre-pectineal (IX) and pterocardiac (II) ossicles.

Pyloric ossicle (III): paired, moderately calcified, convex plate-shaped, inferior portion making connection with a fine fold slightly calcified, connected in the superior portion with exopyloric (IV), propyloric (VI) and anterior mesopyloric (XIX) ossicles, inferior portion free.

Exopyloric ossicle (IV): paired, heavily calcified, small and irregular shaped, lateral margins with firm connection to pyloric (III), zygocardiac (V) and propyloric (VI) ossicles, respectively.

Zygocardiac ossicle (V): paired, well-calcified, wide plateshaped, rigid and irregular, with accentuated dorso-ventral curvature, anterolateral portion narrow making connection with the postpterocardiac ossicle (IIb), medial portion large with 17 to 18 small and sharp denticles, forming the lateral teeth, ventral portion with deep cavity, supporting part of subdentate ossicle (XIV), connection with the exopyloric ossicle (IV).

Propyloric ossicle (VI): unpaired, well-calcified, 'T'-shaped with three equal cavities in the portion connected with pyloric (III) and exopyloric (IV) ossicles, having a central cavity longer, in which, they reach urocardiac ossicle base connection (VII).

Urocardiac ossicle (VII): unpaired, slightly wide, strongly calcified, lateral margin with deep cavity forming two fine folds, anterior extremity larger than posterior one, "T"-shaped, measuring twice posterior portion and fused to mesocardiac ossicle (I), posterior extremity with cavity deep, firmly linked to propyloric ossicle (VI), inner margin with five small teeth (dorsal median tooth).

\section{Lateral supporting cardiac ossicles (Fig. 1)}

Pectineal ossicle (VIII): paired, bearing three to four elongate teeth forming a small comb (accessory tooth) slightly calcified and flexible, outer margin with a pronounced cavity and a fragment well calcified connected with prepectineal (IX) and postpectineal (X) ossicles respectively.

Prepectineal ossicle (IX): paired, firmly calcified, barshaped, with accentuated curvature in the inferior base, anterior and posterior portions with connection to postpterocardiac (IIb) and pectineal (VIII) ossicles, respectively.

Postpectineal ossicle (X): paired, firmly calcified, thin superior extremity curved towards the centre of the foregut, connection with the base of pectineal ossicle (VIII) base, inferior extremity entirely fused to "Quill"(posterior ending of ossicle) of the postpectineal ossicle (Xa), showing a "J"-shaped projection, firm connection of the lateral margin with inferior lateral cardiac ossicle (XIII), with posterior lateral cardiac plate (XII) and with anterior ossicle of the cardio-pyloric valve ossicles (XVI).

Anterior lateral cardiac plate (XI): paired, slightly calcified, irregular shaped, thinned towards lateral margins of the foregut, firm connection with the narrowest portion of posterior lateral cardiac plate (XII).

Posterior lateral cardiac plate (XII): paired, moderately calcified, irregular shaped, firm connection with postpectineal ossicle (X).

Inferior lateral cardiac ossicle (XIII): paired, firmly calcified, superior portion robust, inferior portion narrow, connection with the subdentate ossicle (XIV), anterior (XVI) and lateral (XVIII) ossicles of the cardio-pyloric valve ossicles and cardio-pyloric lateral ossicle.

Subdentate ossicle (XIV): paired, firmly calcified, and showing a slight lateral curvature, superior extremity curved on the cavity of the zygocardiac ossicle $(\mathrm{V})$, posterior extremity, slightly flattened and larger than anterior, showing firm connection with the inferior lateral cardiac ossicle (XIII).

Lateral cardio-pyloric ossicle (XV): paired, moderately calcified, lozenge-shaped, showing firm connection with inferior lateral cardiac ossicle (XIII) and lateral cardio-pyloric valve 
ossicle (XVIII), and showing also connection in the superior portion with anterior supra-ampullary ossicle (XXVIII).

\section{Ossicles of cardio-pyloric valve (Figs 1, 3)}

Ossicles of anterior cardio-pyloric valve (XVI): unpaired, slightly calcified, showing as a fine plate gutter-shaped with a central line firmly calcified dividing the plate in the middle and laterally connected with postpectineal (X) and inferior lateral cardiac (XIII) ossicles.

Posterior ossicle of the cardio-pyloric valve (XVII): unpaired, firmly calcified and subtriangular with a sharp carina exposed horizontally in the surface, connected to the preampullary ossicle (XXII) and cardio-pyloric valve (cpv), firm connection with the ossicles of the lateral ossicle of the cardiopyloric valve (XVIII) and with anterior inferior pyloric ossicle (XXIII).Lateral ossicle of the cardio-pyloric valve (XVIII): paired, firmly calcified, with irregular surface and a distinct lateral curvature, making protection of the cardio-pyloric valve (cpv), firmly connected through to posterior ossicle of the cardiopyloric valve (XVII), lateral cardio-pyloric (XV) and inferior lateral cardiac (XIII) ossicles, connection also with the anterior supra-ampullary ossicle (XXVIII).

Cardio-pyloric valve (cpv): moderately calcified with two prominent protuberances enclosed for long numerous simple setae (not illustrated).

\section{Supporting ossicles of the dorsal pyloric chamber (Figs 1, 2)}

Anterior mesopyloric ossicle (XIX): paired, moderately calcified, showing as plates in which link for fine calcified fold on the superior portion, connection with pyloric (III), lateral mesopyloric (XIXa), posterior mesopyloric (XX) and anterior pleuropyroric (XXXI) ossicles, respectively.

Lateral mesopyloric ossicle (XIXa): paired, slightly calcified, and represented by a paired of fine plates ventrally curved, connected with the anterior mesopyloric (XIX) and anterior pleuropyloric (XXXI) ossicles.

Posterior mesopyloric ossicle (XX): paired, strongly calcified and semi-oval, conection with the anterior mesopyloric (XIX) and anterior pleuropyloric (XXXI) ossicles and, posteriorly, with the uropyloric ossicle (XXI).

Uropyloric ossicle (XXI): unpaired, moderately calcified on the anterior portion; in dorsal view of foregut, shown as an arched piece that opens, side to side, the pyloric chamber, connection in the anterior portion with posterior mesopyloric ossicle (XX).

\section{Supporting ossicles of the ventral pylorus and ampullae (Figs 1, 3)}

Preampullary ossicle (XXII): paired, fine irregular shaped plate moderately calcified, connected with middle supra-ampullary ossicle (XXIX), anterior inferior pyloric (XXIII) and posterior ossicles of the cardio-pyloric valve (XVII) and inferior ampullary ossicle (XXIV).

Anterior inferior pyloric ossicle (XXIII): unpaired, moderately calcified and triangular, partially fused to a fine plate that continue to inferior ampullary ossicle (XXIV), firm connection with the posterior inferior pyloric ossicle (XXVII), posterior ossicle of the cardio-pyloric valve (XVII) and preampullary ossicle (XXII).

Inferior ampullary ossicle (XXIV): par, moderately calcified, showing as a paired of fine convex plates, covered externally by discreet transverse lines in which, making outer protection of the ampullary filter (filter press), connected with preampullary (XXII) and anterior inferior pyloric (XXIII) ossicles, firm connection with the posterior inferior pyloric ossicle (XXVII),

Ampullary roof ossicle, lower portion (XXV): paired, moderately calcified, showing a fine curved plate disposed laterally, fused to ampullary roof ossicle, upper portion (XXVI) and posterior pleuropyloric ossicle (XXXIII), firm connection with middle supra-ampullary ossicle (XXIX).

Ampullary roof ossicle, upper portion (XXVI): paired, firmly calcified shown as a concave plate in the central region, entirely fused in the terminal portion of the pyloric chamber with the posterior pleuropyloric ossicle (XXXIII) and, with ampullary roof ossicle, lower portion (XXV), firm connection with the anterior pleuropyloric ossicle (XXXII).

Posterior inferior pyloric ossicle (XXVII): unpaired, firmly calcified, with irregular plate-shaped and quite curved in the middle, and partially fused with posterior supra-ampullary ossicle $(\mathrm{XXX})$, firm connection with anterior inferior pyloric (XXIIII) and inferior ampullary (XXIV) ossicles.

\section{Supra-ampullary supporting ossicles (Figs 1, 3)}

Anterior supra-ampullary ossicle (XXVIII): paired, moderately calcified, shown as a small concave plate, medial portion with an outstanding and well-calcified fold, firm connection with middle supra-ampullary (XXIX) and with anterior pleuropyloric (XXXI) ossicles, respectively, also connected with the lateral cardio-pyloric ossicle (XV) and lateral ossicle of the cardio-pyloric valve (XVIII).

Middle supra-ampullary ossicle (XXIX): paired, firmly calcified, and shown as an irregular plate with re-entrance in the anterior margin, connection with the preampullary ossicle (XXII) and firm connection with ampullary roof ossicle, lower portion (XXV) and anterior supra-ampullary ossicle (XXVIII).

Posterior supra-ampullary ossicle (XXX): paired, firmly calcified, plate-shaped, partially fused to the centre, also partially fused to the terminal portion of the posterior inferior pyloric ossicle (XXVII) and firm connection with posterior pleuropyloric ossicle (XXXIII).

\section{Supporting ossicles of the lateral pylorus (Fig. 1)}

Anterior pleuropyloric ossicle (XXXI): paired, firmly calcified, shown as an elongated bar, irregular and arched in the terminal portion and with its base formed by a irregular plate, moderately calcified, firm connection with posterior mesopyloric ossicle (XX), ampullary roof ossicle, upper portion (XXVI), anterior supra-ampullary ossicle (XXVIII) and lateral mesopyloric ossicle (XIXa). 
Table I. Ossicles found in the foregut of the freshwater crabs F. reflexifrons, S. pictus, V. serrata and D. septemdentatus.

\begin{tabular}{|c|c|c|c|c|}
\hline Ossicles and plates & F. reflexifrons & S. Pictus & V. serrata & D. septemdentatus \\
\hline \multicolumn{5}{|l|}{ Gastric mill } \\
\hline Mesocardiac & $x$ & $x$ & $x$ & $x$ \\
\hline Pterocardiac & $x$ & $x$ & $x$ & $x$ \\
\hline Pterocardiac & $x$ & $x$ & $x$ & $x$ \\
\hline Urocardiac & $x$ & $x$ & $x$ & $x$ \\
\hline Zygocardiac & $x$ & $x$ & $x$ & - \\
\hline Pyloric ossicle & $x$ & $x$ & $x$ & $x$ \\
\hline Exopyloric & $x$ & $x$ & $x$ & - \\
\hline Propyloric & $x$ & $x$ & $x$ & $x$ \\
\hline \multicolumn{5}{|l|}{ Lateral supporting cardiac ossicles } \\
\hline Pectineal & $x$ & $x$ & $x$ & $x$ \\
\hline Prepectineal & $x$ & $x$ & $x$ & $x$ \\
\hline Postpectineal & $x$ & $x$ & $x$ & $x$ \\
\hline 'Quill' of the postpectineal ossicle & $x$ & $x$ & $x$ & $x$ \\
\hline Anterior lateral cardiac plate & $x$ & $x$ & $x$ & $x$ \\
\hline Posterior lateral cardiac plate & $x$ & $x$ & $x$ & $x$ \\
\hline Inferior lateral cardiac ossicle & $x$ & $x$ & $x$ & $x$ \\
\hline Subdentate & $x$ & $x$ & $x$ & $x$ \\
\hline Lateral cardiac-pyloric ossicle & $x$ & $x$ & $x$ & $x$ \\
\hline \multicolumn{5}{|l|}{ Ossicles of the cardio-pyloric valve } \\
\hline Anterior ossicle of the cardio-pyloric valve & $x$ & $x$ & $x$ & $x$ \\
\hline Posterior ossicle of the cardio-pyloric valve & $x$ & $x$ & $x$ & $x$ \\
\hline Lateral ossicle of the cardio-pyloric valve & $x$ & $x$ & $x$ & $x$ \\
\hline \multicolumn{5}{|l|}{ Supporting ossicles of the dorsal pyloric chamber } \\
\hline Anterior mesopyloric ossicle & $x$ & $x$ & $x$ & $x$ \\
\hline Lateral mesopyloric ossicle & $\mathrm{x}$ & & & \\
\hline Posterior mesopyloric ossicle & $x$ & $x$ & $x$ & $x$ \\
\hline Uropyloric ossicle & $x$ & $x$ & $x$ & $x$ \\
\hline Infra-uropyloric fragment & - & $x$ & $x$ & $x$ \\
\hline Posterior uropyloric & - & $x$ & $x$ & - \\
\hline \multicolumn{5}{|c|}{ Supporting ossicles of the ventral pylorus and ampullae } \\
\hline Preampullary ossicle & $x$ & $x$ & $x$ & $x$ \\
\hline Anterior inferior pyloric ossicle & $x$ & $x$ & $x$ & $x$ \\
\hline Inferior ampullary ossicle & $x$ & $x$ & $x$ & $x$ \\
\hline Ampullary roof ossicle, lower portion & $x$ & $x$ & $x$ & $x$ \\
\hline Ampullary roof ossicle, upper portion & $x$ & $x$ & $x$ & $x$ \\
\hline Posterior inferior pyloric ossicle & $x$ & $x$ & $x$ & $x$ \\
\hline \multicolumn{5}{|l|}{ Supra-ampullary supporting ossicle } \\
\hline Anterior supra-ampullary ossicle & $x$ & $x$ & $x$ & $x$ \\
\hline Middle supra-ampullary ossicle & $x$ & $x$ & $x$ & $x$ \\
\hline Posterior supra-ampullary ossicle & $x$ & $x$ & $x$ & $x$ \\
\hline \multicolumn{5}{|l|}{ Supporting ossicles of the lateral pylorus } \\
\hline Anterior pleuropyloric ossicle & $x$ & $x$ & $x$ & $x$ \\
\hline Middle pleuropyloric ossicle & $x$ & $x$ & $x$ & $x$ \\
\hline Posterior pleuropyloric ossicle & $x$ & $x$ & $x$ & $x$ \\
\hline
\end{tabular}




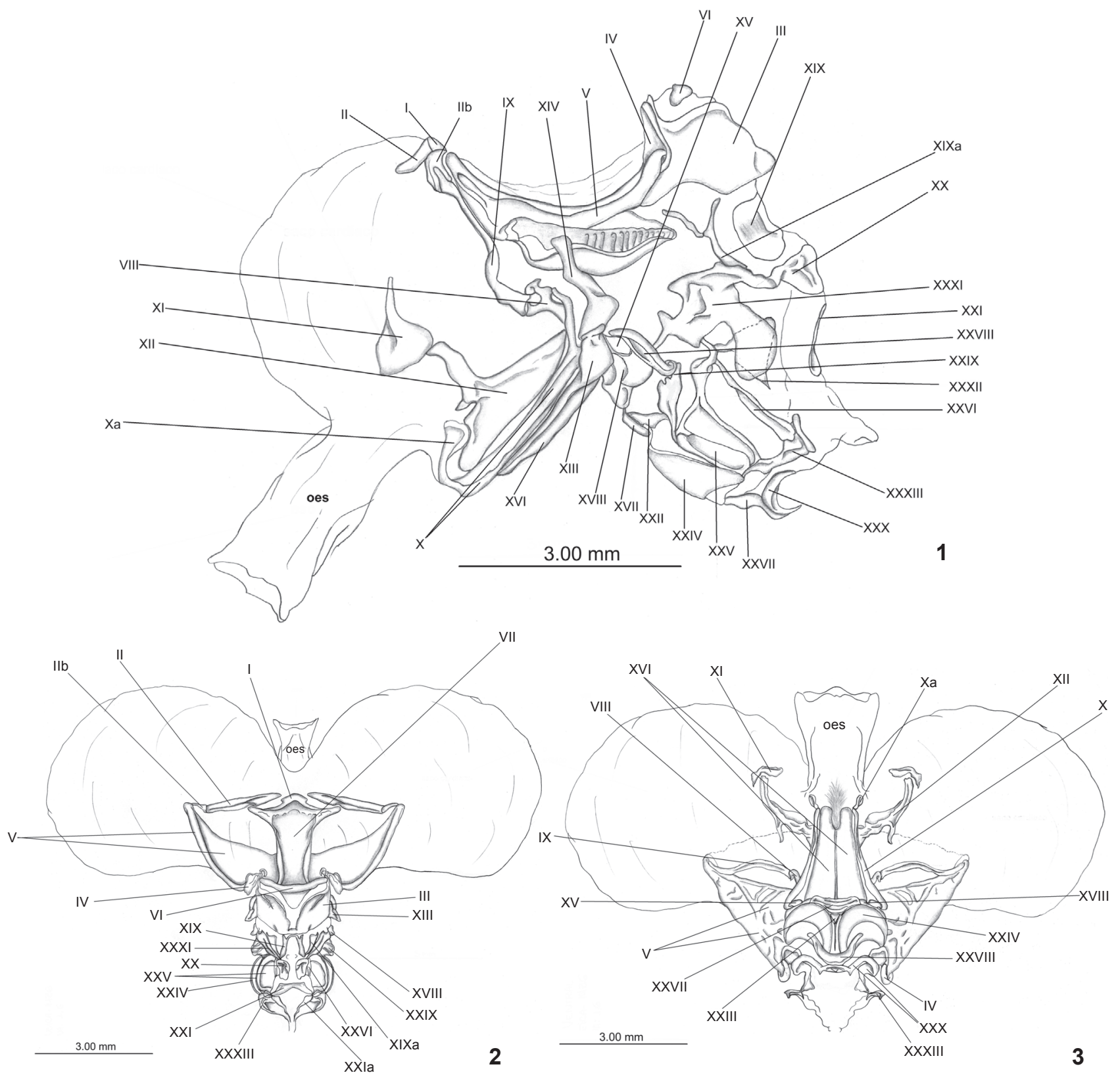

Figures 1-3. Fredius reflexifrons, cardiac and pyloric chambers of the foregut: (1) lateral view; (2) dorsal view; (3) ventral view. Mesocardiac ossicle (I), pterocardiac ossicle (II), postpterocardiac ossicle (IIb), pyloric ossicle (III), exopyloric ossicle (IV), zygocardiac ossicle (V), propyloric ossicle (VI), urocardiac ossicle (VII), pectineal ossicle (VIII), prepectineal ossicle (IX), postpectineal ossicle (X), 'Quill' of the postpectineal ossicle $(\mathrm{Xa})$, anterior lateral cardiac plate $(\mathrm{XI})$, posterior lateral cardiac plate (XII), inferior lateral cardiac ossicle (XIII), subdentate ossicle (XIV), lateral cardio-pyloric ossicle (XV), ossicle of the cardio-pyloric valve (XVI), anterior ossicle of the cardio-pyloric valve $(\mathrm{XVI})$, posterior ossicle of the cardio-pyloric valve (XVII), lateral ossicle of the cardio-pyloric valve (XVIII), anterior mesopyloric ossicle (XIX), lateral mesopyloric ossicle (XIXa), posterior mesopyloric ossicle (XX), uropyloric ossicle (XXI), preampullary ossicle (XXII), anterior inferior pyloric ossicle (XXIII), inferior ampullary ossicle (XXIV), ampullary roof ossicle, lower portion ossicle (XXV), ampullary roof ossicle, upper portion ossicle (XXVI), posterior inferior pyloric ossicle (XXVII), anterior supra-ampullary ossicle (XXVIII), middle supra-ampullary ossicle $(X X I X)$, posterior supra-ampullary ossicle $(X X X)$, anterior pleuropyloric ossicle $(X X X I)$, middle pleuropyloric ossicle (XXXII), posterior pleuropyloric ossicle (XXXIII). 
Middle pleuropyloric ossicle (XXXII): paired, moderately calcified, subtriangular plate-shaped, firm connection with ampullary roof-superior portion (XXVI) and located under the anterior pleuropyloric ossicle (XXXI).

Posterior pleuropyloric ossicle (XXXIII): paired, firmly calcified, robust, irregular, short and slightly curved, partially fused to ampullary roof ossicle, lower portion ossicle (XXV) and ampullary roof ossicle, upper portion (XXVI), firm connection with posterior supra-ampullary ossicle (XXX).

\section{Foregut ossicles of Sylviocarcinus pictus}

Oesophagus short connected with ventral portion of the cardiac chamber; cardiac chamber wider and little longer than pyloric chamber bearing 17 ossicle; pyloric chamber with 17 ossicles, little shorter than cardiac chamber with the terminal portion slightly curved upward in the apex; cardiac sac small and heart shaped.

\section{Ossicles of the gastric mill (Figs 4, 5)}

Mesocardiac ossicle (I): unpaired, firmly calcified, accentuated re-entrance in the base completely fused with urocardiac ossicle (VII), anterior portion free, with soft re-entrance, lateral margin wide with firm connection in the inner lateral margin of the pterocardiac ossicle (II).

Pterocardiac ossicle (II): paired, subtriangular, firmly calcified with small concavities in the surface, left lateral margin with firm connection to postpterocardiac ossicle (IIb) and right inner lateral margin with mesocardiac ossicle (I).

Postpterocardiac (IIb): paired, slightly calcified, irregular, narrow and short, firmly linked in the right extremity with pterocardiac ossicle (II), ventral connection with prepectineal (IX) and to zygocardiac (V) ossicles.

Pyloric ossicle (III): paired, moderately calcified, convex, anterior portion with firm connection to pyloric ossicle (VI), inferior and lateral portions (left and right) firmly connected with exopyloric ossicle (IV).

Exopyloric ossicle (IV): paired, firmly calcified, ovalshaped, firm connection with the pyloric ossicle (III) and ventrally with zygocardiac ossicle (V).

Zygocardiac ossicle $(\mathrm{V})$ : paired, firmly calcified, dorsoventrally curved, left anterolateral portion connected with postpterocardiac ossicle (IIb), firm connection with exopyloric ossicle (IV), medial portion large forming a plate with depressions in the surface bearing from seven to eight small short denticles constituting the lateral teeth, ventral portion with deep cavity supporting part of the subdentate ossicle (XIV) and showing firm connection. Propyloric ossicle (VI): unpaired, firmly calcified, log glass-shaped, inferior base smaller than superior and firmly linked to urocardiac ossicle (VII) in the inner portion of foregut, superior base connected through firm connection with the pyloric (III) and exopyloric (IV) ossicles.

Urocardiac ossicle (VII): unpaired, firmly calcified, long, wide in the superior region and little narrower in the inferior region, " $\mathrm{T}$ "-shaped, inferior region with deep cavity forming two fine folds in the lateral side, fused to the mesocardiac ossicle (I) in the superior region and linked to propyloric ossicle (VI), inner margin with three to four protuberant teeth in screw shaped.

\section{Lateral supporting cardiac lateral ossicles (Fig. 4)}

Pectineal ossicle (VIII): paired, moderately calcified, short, fine, curved to the centre, bearing three to four fine and sharp teeth forming a small comb (accessory tooth), firm connection in the left extremity with prepectineal ossicle (IX), right extremity with postpectineal ossicle (X) and posterior lateral cardiac plate (XII).

Prepectineal ossicle (IX): paired, firmly calcified, and curved stick-shaped in the inferior extremity, superior portion with connection to postpterocardiac (IIb) and in the inferior portion bearing firm connection with pectineal (VIII) ossicles, respectively. Postpectineal ossicle (X): paired, firmly calcified, superior extremity thin and curved towards the centre of the foregut with firm connection to the base of the pectineal ossicle (VIII), inferior extremity completely fused "Quill" (posterior ending) of ossicle of postpectineal (Xa) forming a projection "J"-shaped, firm connection to the inferior lateral cardiac ossicle (XIII) and posterior lateral cardiac plate (XII).

Anterior lateral cardiac plate (XI): paired, slightly calcified, irregular shaped, partially fused to the posterior lateral cardiac plate (XII).

Posterior lateral cardiac plate (XII): paired, irregularly shaped, enlarged, moderately calcified in the borders, slightly calcified and concave in the centre, with firm connection to postpectineal ossicle (X) and partially fused to anterior lateral cardiac plate (XI).

Inferior lateral cardiac ossicle (XIII): paired, firmly calcified, enlarged, quite robust in the superior and with terminal portion acute, superior portion firm connection with subdentate (XIV), lateral cardio-pyloric (XV) ossicle of anterior cardio-pyloric valve (XVI) and postpectineal (X) ossicles.

Subdentate ossicle (XIV): paired, firmly calcified, and showing light lateral curvature, superior extremity curved on the cavity of the zygocardiac ossicle (V), inferior extremity slightly flat and more enlarged than superior, firm connection with the inferior lateral cardiac ossicle (XIII) in its base.

Lateral cardio-pyloric ossicle (XV): paired, moderately calcified, irregular plate-shaped, firm connection with the inferior lateral cardiac ossicle (XIII) and lateral ossicle of the cardio-pyloric valve (XVIII), connection in the superior portion with anterior supra-ampullary ossicle (XXVIII).

\section{Ossicles of the cardio-pyloric valve (Fig. 6)}

Anterior ossicle of the cardio-pyloric valve (XVI): unpaired, slightly calcified, forming a plate gutter-shaped, lateral connection with postpectineal ossicle (X) and lateral ossicle of the valve cardio-pyloric (XVIII) in the base.

Posterior ossicle of the cardio-pyloric valve (XVII): unpaired, firmly calcified, semi-oval, with carina in the surface, connection with ossicle of lateral cardio-pyloric valve (XVIII), 

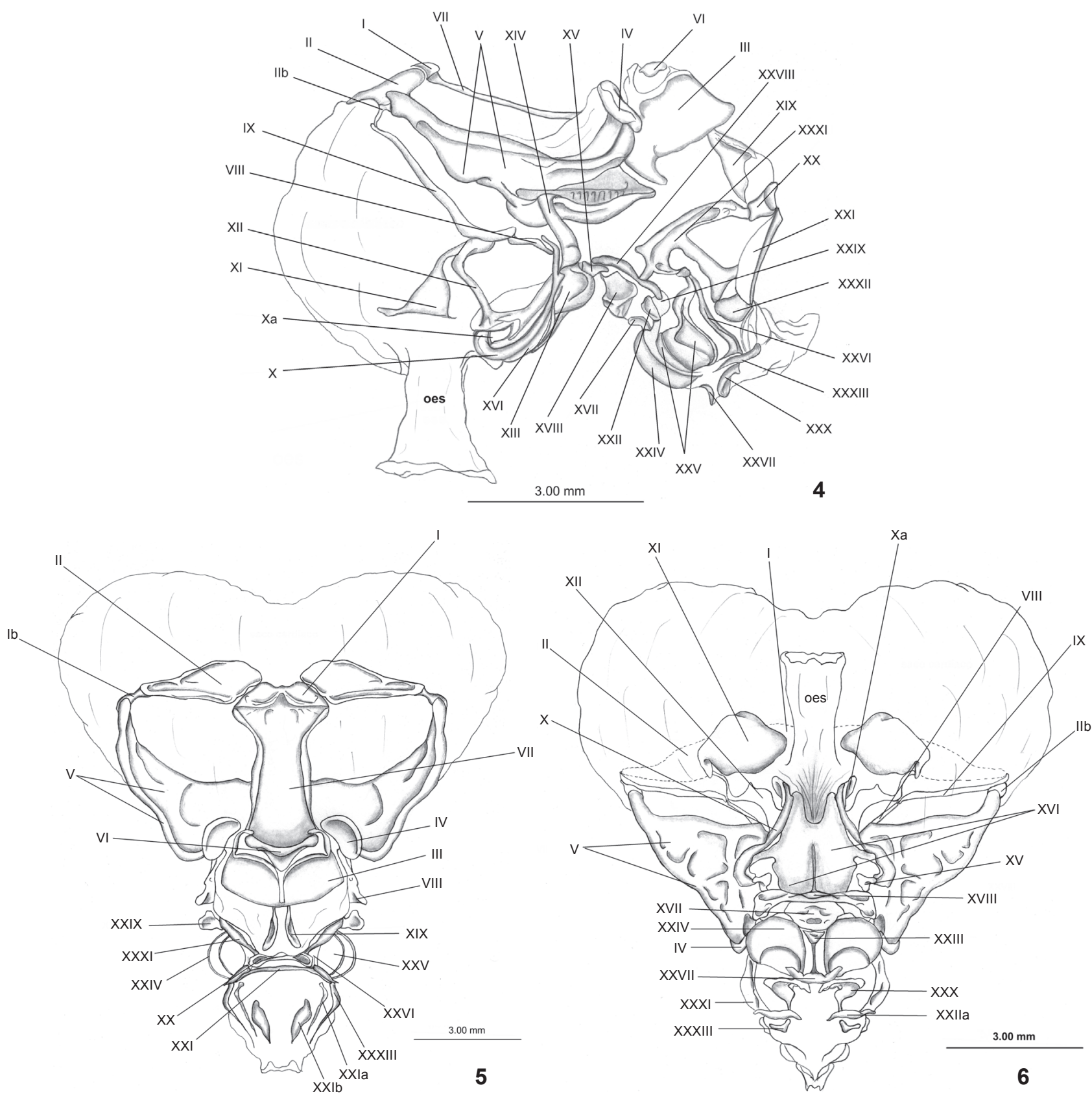

Figures 4-6. Sylviocarcinus pictus, cardiac and pyloric chambers of the foregut: (4) lateral view; (5) dorsal view; (6) ventral view. Mesocardiac ossicle (I), pterocardiac ossicle (II), postpterocardiac ossicle (IIb), pyloric ossicle (III), exopyloric ossicle (IV), zygocardiac ossicle (V), propyloric ossicle (VI), urocardiac ossicle (VII), pectineal ossicle (VIII), prepectineal ossicle (IX), postpectineal ossicle (X), 'Quill' of the postpectineal ossicle $(\mathrm{Xa})$, anterior lateral cardiac plate $(\mathrm{XI})$, posterior lateral cardiac plate (XII), inferior lateral cardiac ossicle (XIII), subdentate ossicle (XIV), lateral cardio-pyloric ossicle (XV), ossicle of the cardio-pyloric valve (XVI), anterior ossicle of the cardio-pyloric valve $(\mathrm{XVI})$, posterior ossicle of the cardio-pyloric valve (XVII), lateral ossicle of the cardio-pyloric valve (XVIII), anterior mesopyloric ossicle (XIX), posterior mesopyloric ossicle (XX), uropyloric ossicle (XXI), preampullary ossicle (XXII), inferior ampullary ossicle (XXIV), ampullary roof ossicle, lower portion ossicle $(X X V)$, ampullary roof ossicle, upper portion ossicle (XXVI), posterior inferior pyloric ossicle $(X X V I I)$, anterior supra-ampullary ossicle (XXVIII), middle supra-ampullary ossicle (XXIX), posterior supra-ampullary ossicle (XXX), anterior pleuropyloric ossicle (XXXI), middle pleuropyloric ossicle (XXXII), posterior pleuropyloric ossicle (XXXIII). 
preampullary ossicle (XXII), firm connection with anterior inferior pyloric ossicle (XXIII) and cardio-pyloric valve (cpv).

Lateral ossicle of the cardio-pyloric valve (XVIII): paired, firmly calcified, irregular shaped, similar to a curved plate towards the centre of the foregut, with protection of the cardiopyloric valve (cpv), connection with posterior ossicle of the cardio-pyloric valve (XVII).

Cardio-pyloric valve: moderately calcified, showing two lobes covered by numerous and long simple setae (not illustrated).

\section{Supporting ossicles of the dorsal pyloric chamber (Figs 4-5)}

Anterior mesopyloric ossicle (XIX): paired, moderately calcified, and showing as convex and wide plate, connection with pyloric ossicle (III) and with anterior pleuropyloric ossicle (XXXI).

Posterior mesopyloric ossicle (XX): paired, firmly calcified, semi-oval and concave in the centre, firmly linking to anterior pleuropyloric ossicle (XXXI) and posteriorly with the uropyloric ossicle (XXI). Uropyloric ossicle (XXI): unpaired, moderately calcified, and showing as a fine semi-arch opening in the pyloric chamber, connection with posterior mesopyloric (XX) and infra-uropyloric fragment (XXIa).Infra-uropyloric fragment: paired, moderately calcified, long and thin, curved in the superior portion, connection with the posterior uropyloric (XXIb) and uropyloric (XXI) ossicles.

\section{Supporting ossicles of the ventral pylorus and ampullae (Figs 4, 6)}

Preampullary ossicle (XXII): paired, moderately calcified, and showing as a small plate, connection with supra-ampullary (XXIX), anterior inferior pyloric (XXIII), inferior ampullary (XXIV) ossicles and posterior ossicle of the cardio-pyloric valve (VVII)

Anterior inferior pyloric ossicle (XXIII): unpaired, moderately calcified, subtriangular-shaped and partially fused to a fine plate that continue to inferior ampullary ossicle (XXIV), connection with posterior ossicle of the cardio-pyloric valve (XVII), posterior inferior pyloric ossicle (XXVII) and preampullary ossicle (XXII).

Inferior ampullary ossicle (XXIV): paired, moderately calcified, showing as a paired of fine convex plates, guttershaped, surface covered by fine traverse making protection to the ampullary filter (filter press), connection with preampullary (XXII), anterior inferior pyloric (XXIII) and posterior inferior pyloric (XXVII) ossicles.

Ampullary roof ossicle, lower portion (XXV): paired, moderately calcified, showing as a fine plate disposed laterally and fused to ampullary roof ossicle, upper portion (XXV), connection with posterior pleuropyloric (XXXIII) and middle supra-ampullary (XXIX) ossicles.

Ampullary roof ossicle, upper portion (XXVI): paired, firmly calcified, concave in the central region, firm connection with posterior pleuropyloric (XXXIII) and ampullary roof ossicle, lower portion (XXV) ossicles, showing the superior extremity partially fused to the anterior pleuropyloric ossicle (XXXI).

Posterior inferior pyloric ossicle (XXVII): unpaired, firmly calcified, shown as an irregular and concave plate, stick shaped with the tips upward in the ventral view, connections with anterior inferior pyloric (XXIII), posterior supra-ampullary (XXX) and inferior ampullary (XXIV) ossicles.

\section{Supra-ampullary supporting ossicles (Figs 4, 6)}

Anterior supra-ampullary ossicle (XXVIII): paired, moderately calcified, narrow and irregular plate-shaped, connections with middle supra-ampullary (XXIX), anterior pleuropyloric (XXXI), lateral cardio-pyloric (XV) ossicle and ossicle of the lateral cardio-pyloric valve (XVIII).

Middle supra-ampullary ossicle (XXIX): paired, strongly calcified, showing as a small plate, connection with preampullary (XXII) and anterior supra-ampullary (XXVIII) ossicles and ampullary roof ossicle, lower portion (XXV).

Posterior supra-ampullary ossicle (XXX): paired, firmly calcified, showing as irregular plates, connection in the terminal portion with the posterior inferior pyloric ossicle (XXVII) and posterior pleuropyloric ossicle (XXXIII).

Supporting ossicles of the lateral pylorus (Figs 4 and 5)

Anterior pleuropyloric ossicle (XXXI): paired, firmly calcified, showing as elongated and curved bars, irregular and moderately calcified, plate-shaped in the base, connection with posterior mesopyloric (XX), ampullary roof, upper portion (XXVI) and anterior supra-ampullary (XXVIII) and middle pleuropyloric (XXXII) ossicles.

Middle pleuropyloric ossicle (XXXII): paired, slightly calcified, small irregular plate-shaped, connection with anterior pleuropyloric ossicle (XXXI). Posterior pleuropyloric ossicle (XXXIII): paired, firmly calcified, short, irregular plate-shaped, short, narrow and slightly curved, connection with ampullary roof, upper portion (XXVI), ampullary roof, lower portion $(\mathrm{XXV})$ and posterior supra-ampullary (XXX) ossicles.

\section{Foregut ossicles of Valdivia serrata}

Oesophagus long and slightly bent forward, connecting with the ventral region of the foregut; the cardiac chamber showing wider than long bearing 17 ossicles; pyloric chamber with 17 ossicles, little shorter than cardiac with terminal portion bent downward $90^{\circ}$.

\section{Ossicles of the gastric mill (Figs 8, 9)}

Mesocardiac ossicle (I): unpaired, superior portion strongly calcified, " $\mathrm{V}$ "-shaped, entirely fused to urocardiac ossicle (VII), anterior portion free and subtriangular, lateral margins narrow making connection with the superior extremity and lateral right of pterocardiac ossicle (II).Pterocardiac ossicle (II): paired, portion turned to mesocardiac ossicle (I) more enlarged and moderately calcified, portion turned to zygocardiac ossicle (V), narrow and strongly calcified and connected to postpterocardiac ossicle (IIb). 
Postpterocardiac ossicle (IIb): paired, slightly calcified, irregular, left lateral extremity making connection with zygocardiac ossicle (V), right lateral extremity bifurcated, making connection with prepectineal (IX) and pterocardiac (II) ossicle.

Pyloric ossicle (III): paired, moderately calcified, convex, gutter shaped, inferiorly linked for a fine fold, slightly calcified, anterior portion concave, making firm connection with propyloric ossicle (VI), inferior portion free, lateral margin connected with exopyloric ossicle (IV).

Exopyloric ossicle (IV): paired, strongly calcified, semioval-shaped with irregular margins, connection with pyloric ossicle (III) and ventrally with zygocardiac ossicle (V).

Zygocardiac ossicle (V): paired, strongly calcified, ventrally curved backward, with pronounced medial depression, anterolateral margin narrow, connection with postpterocardiac ossicle (IIb), margin turned to the medial portion of the widest chamber with nine small flat teeth (lateral teeth), ventral portion with deep cavity sheltering part of the subdentate ossicle (XIV).

Propyloric ossicle (VI): unpaired, strongly calcified, ' $\mathrm{Y}$ 'shaped with a long central cavity reaching the base of urocardiac ossicle (VII), connection with pyloric (III) and urocardiac (VII) ossicles.

Urocardiac ossicle (VII): unpaired, strongly calcified, " $\mathrm{T}$ "shaped, long, anterior extremity little wider than the posterior, outer lateral margins with large and deep cavity forming two fine folds, anterior extremity " $\mathrm{T}$ "-shaped and fused to mesocardiac ossicle (I), posterior extremity connected with propyloric ossicle (VI) bearing four robust teeth in screw (dorsomedian tooth).

\section{Lateral supporting cardiac ossicles (Fig. 8)}

Pectineal ossicle (VIII): paired, moderately calcified, short, robust and curved to the centre, lacking teeth but with numerous long and simple setae, outer margin with discreet cavity, connected in the left extremity through firm connection with the prepectineal ossicle (IX) and in the right extremity with the postpectineal ossicle $(\mathrm{X})$, with firm connection also with posterior lateral cardiac plate (XII).

Prepectineal ossicle (IX): paired, firmly calcified, long stick-shaped, curved in the inferior extremity, upper portion of the ossicle connected with to postpterocardiac ossicle (IIb), inferior portion with firm connection to pectineal ossicle (VIII).

Postpectineal ossicle (X): paired, firmly calcified, long and fine, with thin and curved extremity and towards to the centre of the cardiac chamber, firm connection to the base of the pectineal ossicle (VIII), inferior extremity whole fused to the "Quill" (posterior ending of ossicle) of the postpectineal ossicle (Xa), showing a projection "J"-shaped, firm connection with inferior lateral cardiac ossicle (XIII) and with posterior lateral cardiac plate (XII).

Anterior lateral cardiac plate (XI): paired, slightly calcified, semi-rectangle-shaped, with accentuated carina in the base, firm connection with posterior lateral cardiac plate (XII), firm connection with posterior lateral cardiac plate (XII).

Posterior lateral cardiac plate (XII): paired, irregular shaped, moderately calcified in the borders and slightly calcified in the centre, enlarged and concave in the portion in which connect to postpectineal ossicle $(\mathrm{X})$ in the medial area, connection with anterior lateral cardiac plate (XI) with irregular surface.

Inferior lateral cardiac ossicle (XIII): paired, firmly calcified, robust in the superior and very fine in the inferior portion, firm connection with subdentate ossicle (XIV), ossicles of the valve anterior cardio-pyloric valve (XVI), lateral cardiopyloric ossicle (XV) and postpectineal ossicle (X).

Subdentate ossicle (XIV): paired, firmly calcified, stickshaped with light lateral curvature, superior extremity curved on the cavity of the zygocardiac ossicle $(\mathrm{V})$, posterior extremity more enlarged than anterior with firm connection to inferior lateral cardiac ossicle (XIII).

Lateral cardio-pyloric ossicle (XV): paired, moderately calcified and subtriangular, firm connection with inferior lateral cardiac ossicle (XIII) and lateral ossicle of the cardio-pyloric valve (XVIII), connection with the superior portion of the anterior supra-ampullary in the superior portion (XXVIII).

\section{Ossicles of the cardio-pyloric valve (Fig. 9)}

Anterior ossicle of the cardio-pyloric valve (XVI): unpaired, irregular shaped, slightly calcified in the lateral margins forming a fine plate, gutter-shaped and moderately calcified to the centre forming a medium line, connected sidelong through firm connection with postpectineal (X) and inferior lateral cardiac (XIII) ossicles.

Posterior ossicle of the cardio-pyloric valve (XVII): unpaired, firmly calcified and subtriangular, connection with ossicle of the valve lateral cardio-pyloric valve (XVIII), preampullary ossicle (XXII) and firm connection with anterior inferior pyloric ossicle (XXIII) and cardio-pyloric valve (cpv).

Lateral cardio-pyloric valve (XVIII): paired, firmly calcified, irregular shaped, similar to a curved plate towards the centre of the cardiac chamber, links through connection with the posterior ossicle of the cardio-pyloric valve (XVII).

Cardio-pyloric valve (cpv): moderately calcified, bearing two lobes covered by numerous and long simple setae. (not illustrated).

\section{Supporting ossicles of the dorsal pyloric chamber (Figs 7, 8)}

Anterior mesopyloric ossicle (XIX): paired, moderately calcified, convex with large plates, anteriorly connected with pyloric ossicle (III).

Posterior mesopyloric ossicle (XX): paired, firmly calcified, semi-oval and concave in the centre, firmly linked to anterior pleuropyloric ossicle (XXXI) and posteriorly with uropyloric ossicle (XXI).

Uropyloric ossicle (XXI): unpaired, firmly calcified, fine arch-shaped opening in the pyloric chamber, connection with posterior mesopyloric ossicle (XX), infra-uropyloric fragment 
(XXIa) and posterior uropyloric ossicle (XXIb).Infra-uropyloric fragment (XXIa): paired, moderately calcified, shown as a long and fine ossicle with small curvature in the superior portion, firm connection with uropyloric ossicle (XXI) and connection with middle pleuropyloric ossicle (XXXII).

Posterior uropyloric ossicle (XXIb): paired, slightly calcified, showing as a small forked plate in the inferior extremity, connection with uropyloric (XXI) and posterior pleuropyloric (XXXIII) ossicles.

\section{Supporting ossicles of the ventral pylorus and ampullae (Figs 7, 9)}

Preampullary ossicle (XXII): paired, moderately calcified, and showing as a small and narrow plate, connection with middle supra-ampullary (XXIX), anterior inferior pyloric (XXIII), the inferior ampullary ossicles (XXIV) and posterior ossicle of the cardio-pyloric valve (XVII).

Anterior inferior pyloric ossicle (XXIII): paired, moderately calcified, triangular and partially fused with a fine plate in which continue in the inferior ampullary ossicle (XXIV), firm connection in the superior extremity with the ossicle of pyloric valve (XVII) and, in the inferior extremity, with ossicle inferior posterior pyloric (XXVII), connection with preampullary ossicle (XXII).Inferior ampullary ossicle (XXIV): paired, moderately calcified, showing as a paired of fine convex plates, gutter-shaped, surface covered by fine traverse lines with outer protection of ampullary filter (filter press), firm connection with posterior inferior pyloric ossicle (XXVII) and preampullary ossicle (XXII) and with anterior inferior pyloric ossicle (XXIII) separating the two plates.Ampullary roof ossicle, lower portion (XXV): paired, moderately calcified, showing laterally as a disposed fine plate, fused to ampullary roof ossicle, upper portion (XXVI), firm connection with ossicle middle supra-ampullary ossicle (XXIX) and with posterior supra-ampullary ossicle $(\mathrm{XXX})$. Ampullary roof ossicle, upper portion (XXVI): paired, firmly calcified, showing as a semicircular plate, concave in the central area, firm connection with posterior pleuropyloric ossicle (XXXIII) and with the ossicle of ampullary roof ossicle, lower portion (XXV) and partially fused to anterior pleuropyloric ossicle (XXXI).

Posterior inferior pyloric ossicle (XXVII): unpaired, firmly calcified, shown as an irregular and concave plate, firm connection with posterior supra-ampullary ossicle (XXX), anterior inferior pyloric ossicle (XXIII) and inferior ampullary ossicle (XXIV).

\section{Supra-ampullary supporting ossicles (Figs 7, 9)}

Anterior supra-ampullary ossicle (XXVIII): paired, moderately calcified, plate-shaped, little enlarged, concave and irregular, firmly linked to middle supra-ampullary (XXIX) and to anterior pleuropyloric (XXXI) ossicles, connection with lateral cardio-pyloric ossicle (XV) and lateral ossicles of the cardiopyloric valve (XVIII).
Middle supra-ampullary ossicle (XXIX): paired, moderately calcified, showing as a small plate, a little enlarged and irregular shaped, connection with preampullary (XXII), firm connection with anterior supra-ampullary (XXVIII) ossicles and ampullary roof ossicle, lower portion (XXV).

Posterior supra-ampullary ossicle (XXX): paired, firmly calcified, showing as two irregular plates, partially fused, firm connection with the terminal portion of posterior inferior pyloric ossicle (XXVII) and to ampullary roof ossicle, lower portion (XXV) and partially fused to ossicle of the ampullary roof ossicle, upper portion (XXVI).

\section{Supporting ossicles of the lateral pylorus (Figs 7 and 8)}

Anterior pleuropyloric ossicle (XXXI): paired; firmly calcified, shown as elongate plates, irregular shaped and with a central carina along the plate, showing a triangular expansion, slightly calcified from the medial portion, firm connection with posterior mesopyloric (XX), anterior supra-ampullary ossicles (XXVIII) and partially fused to ampullary roof ossicle, upper portion (XXVI).

Middle pleuropyloric ossicle (XXXII): paired, slightly calcified, semicircular, irregular surface located below of the anterior pleuropyloric ossicle (XXXI) and linked to infrauropyloric fragment (XXIa).

Posterior pleuropyloric ossicle (XXXIII): paired, firmly calcified, short, and plate-shaped with irregular borders, linked loosely to posterior uropyloric ossicle (XXIb) and to ampullary roof ossicle, upper portion (XXVI).

\section{Foregut ossicles of Dilocarcinus septemdentatus}

The oesophagus connecting with antero-ventral portion of the cardiac chamber slightly bent to anterior area; cardiac chamber showing wider than long with 17 ossicles; pyloric chamber little shorter than cardiac, terminal portion bent downward bearing 16 ossicles and cardio-pyloric valve with four ossicles.

\section{Ossicles of the gastric mill (Figs 10,11)}

Mesocardiac ossicle (I): unpaired, moderately calcified, subtriangular, firmly calcified in the portion fused to urocardiac ossicle (VII), lateral margins with firm connection to pterocardiac ossicle (II).

Pterocardiac ossicle (II): paired, strongly calcified, showing an enlarged plate in the portion linking to mesocardiac ossicle (I) and narrower in the portion connected with postpterocardiac ossicle (IIb).

Postpterocardiac ossicle (IIb): paired, slightly calcified, irregular shaped, left lateral extremity with connection to zygocardiac ossicle (V), right lateral extremity with connection to pterocardiac ossicle (II) and ventral extremity with connection to pre-pectineal ossicle (IX).

Pyloric ossicle (III): paired, moderately calcified, convex, large and convex plates-shaped, inferiorly linked for a fine fold, slightly calcified, sheltering the propyloric ossicle (VI), firm connection with exopyloric ossicle (IV) and laterally to propyloric ossicle (VI). 

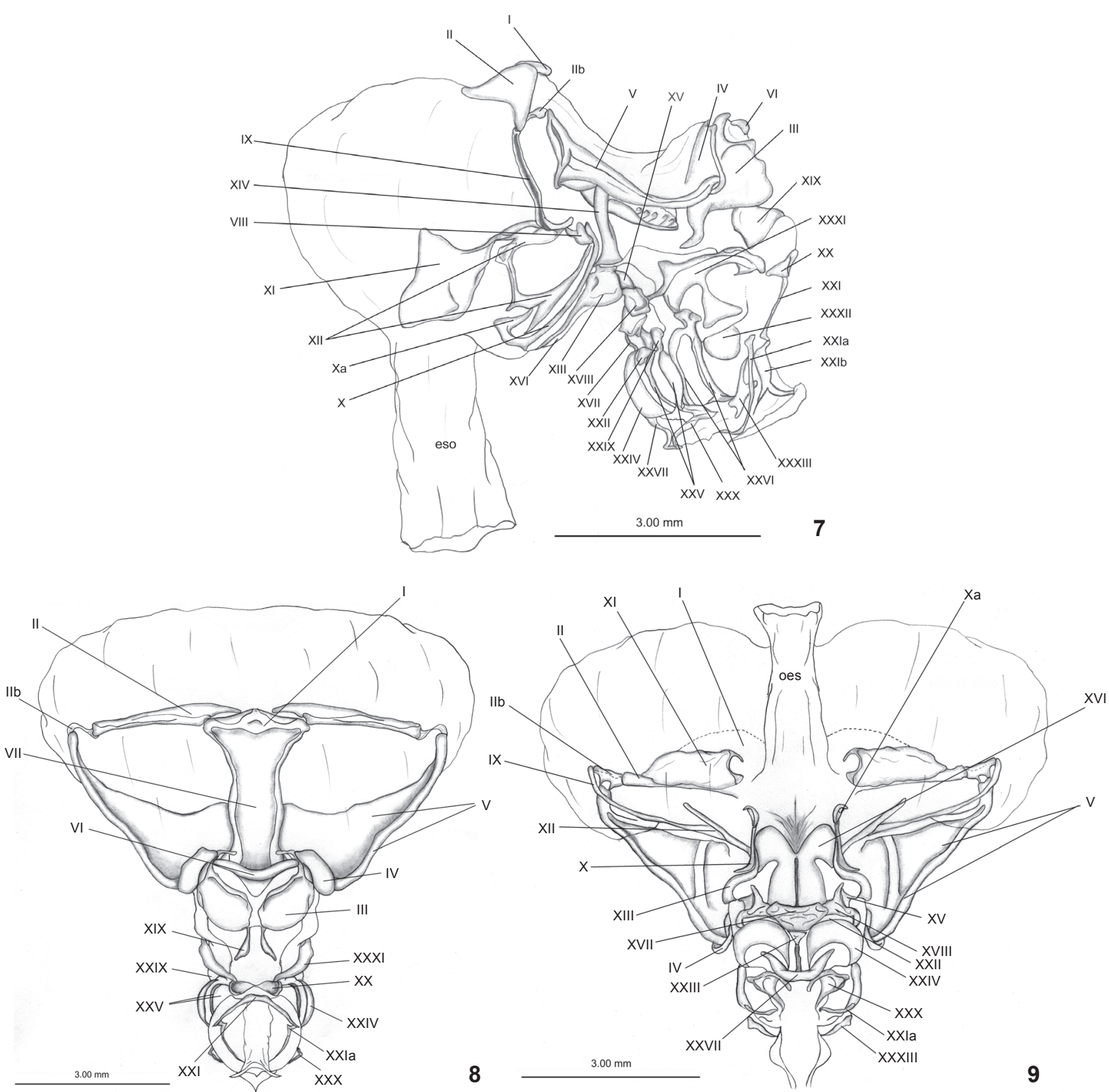

Figures 7-9. Valdivia serrata, cardiac and pyloric chambers of the foregut: (7) lateral view; (8) dorsal view; (9) ventral view. Mesocardiac ossicle (I), pterocardiac ossicle (II), postpterocardiac ossicle (Ilb), pyloric ossicle (III), exopyloric ossicle (IV), zygocardiac ossicle (V), propyloric ossicle $(\mathrm{VI})$, urocardiac ossicle $(\mathrm{VII})$, pectineal ossicle (VIII), prepectineal ossicle (IX), postpectineal ossicle (X), 'Quill' of the postpectineal ossicle (Xa), anterior lateral cardiac plate (XI), posterior lateral cardiac plate (XII), inferior lateral cardiac ossicle (XIII), subdentate ossicle (XIV), lateral ossicle of the cardio-pyloric (XV), ossicle of the cardio-pyloric valve (XVI), cardio-pyloric valve (cpv), anterior ossicle of the cardio-pyloric valve (XVI), posterior ossicle of the cardio-pyloric valve (XVII), lateral ossicle of the cardio-pyloric valve (XVIII), anterior mesopyloric ossicle (XIX), posterior mesopyloric ossicle (XX), uropyloric ossicle (XXI), infra-uropyloric fragment (XXIa), posterior uropyloric ossicle (XXIb), preampullary ossicle (XXII), anterior inferior pyloric ossicle (XXIII), inferior ampullary ossicle (XXIV), ampullary roof ossicle, lower portion ossicle (XXV), ampullary roof ossicle, upper portion ossicle (XXVI), posterior inferior pyloric ossicle (XXVII), middle supra-ampullary ossicle (XXIX), posterior supra-ampullary ossicle (XXX), anterior pleuropyloric ossicle (XXXI), middle pleuropyloric ossicle (XXXII), posterior pleuropyloric ossicle (XXXIII). 
Exopyloric ossicle (IV): paired, firmly calcified, elliptical-shaped with discreet irregular concavity in the centre, connection with pyloric (III) and zygocardiac (V) ossicles.

Zygocardiac ossicle (V): paired, firmly calcified and dorsoventrally curved downward, antero-lateral portion narrow with connection to postpterocardiac (IIb) and exopyloric (IV) ossicles, medial portion quite enlarged with nine small flat teeth forming the lateral teeth, ventral portion with deep cavity supporting part of the subdentate ossicle (XIV).

Propyloric ossicle (VI): unpaired, strongly calcified, log glass-shaped with superior region more larger than inferior, showing a inner central cavity located in the largest region, connection with pyloric (III), exopyloric ossicle (IV) and urocardiac ossicle (VII) in the inner base.

Urocardiac ossicle (VII): unpaired, firmly calcified, short, " $\mathrm{T}$ "-shaped, superior portion large and inferior portion narrow, inferior portion with a deep cavity forming two fine lateral folds fused to mesocardiac ossicle (I), posterior extremity connecting with propyloric ossicle (VI), inner margin bearing three to four teeth, screw-shaped (dorsal teeth).

\section{Lateral supporting cardiac ossicles (Fig. 10)}

Pectineal ossicle (VIII): paired, moderately calcified, short, curved in the centre, irregular shaped, bearing three to four fine and sharp teeth forming the accessory teeth, small comb slightly calcified and flexible, firm connection with prepectineal (IX) and postpectineal (X) ossicles and posterior lateral cardiac plate (XII) ossicles.

Prepectineal ossicle (IX): paired, strongly calcified, long and curved stick-shaped with inferior extremity " $L$ "-shaped, superior portion with connection to postpterocardiac (IIb) and pectineal (VIII) ossicles.

Postpectineal ossicle (X): paired, showing strong calcification, long stick-shaped enlarged in the base, superior extremity thin and curved in the cardiac chamber centre, connection with the base of pectineal ossicle (VIII), the inferior extremity entirely fused to "Quill" (posterior ending of ossicle) of postpectineal ossicle (Xa) forming a projection "J"-shaped, connection with inferior lateral cardiac ossicle (XIII) and posterior lateral cardiac plate (XIII). Anterior lateral cardiac plate (XI): paired, irregular and slightly calcified, connection with posterior lateral cardiac plate (XII).

Posterior lateral cardiac plate (XII): paired, moderately calcified in the borders and slightly calcified in the centre, showing as an irregular plate, large and concave in the centre, strong connection with pectineal (VIII) and postpectineal (X) ossicles and with the anterior lateral cardiac plate (XI).Inferior lateral cardiac ossicle (XIII): paired, strongly calcified, robust, large with rounded margins and acute in the inferior portion, firm connection with subdentate ossicle (XIV), anterior ossicle of the cardio-pyloric valve (XVI), lateral cardio-pyloric (XV) and postpectineal $(\mathrm{X})$ ossicles.

Subdentate ossicle (XIV): paired, firmly calcified, short stick-shaped with a light lateral curvature, superior extremity curved on the cavity of the zygocardiac ossicle $(\mathrm{V})$, posterior extremity slightly flatted and more enlarged than anterior with connection to inferior lateral cardiac ossicle (XIII).

Lateral cardio-pyloric ossicle (XV): paired, firmly calcified and subtriangular, firm connection with inferior lateral cardiac ossicle (XIII) and lateral ossicle of cardio-pyloric valve (XVIII), connection in the superior portion with anterior supra-ampullary ossicle (XXVIII)

\section{Ossicles of the cardio-pyloric valve (Figs 10,12)}

Anterior ossicle of the cardio-pyloric valve (XVI): unpaired, moderately calcified, showing as a fine plate, guttershaped, with firmly calcified line along the plate dividing in the middle, connection with postpectineal (X) and inferior lateral cardiac (XIII) ossicles.

Posterior ossicle of the cardio-pyloric valve (XVII): unpaired, moderately calcified, ellipse-shaped, showing an irregular surface with few sharp carina, connection with preampullary ossicle (XXII), lateral ossicle of the cardio-pyloric valve (XVIII), anterior inferior pyloric ossicle (XXIII) and cardio-pyloric valve (cpv).

Lateral ossicle of the cardio-pyloric valve (XVIII): paired, firmly calcified, irregular, showing a small carina in the surface, and distinct lateral curvature with protection of the cardiopyloric valve (cpv), connection with posterior ossicle of the cardio-pyloric valve (XVII).

Cardio-pyloric valve (cpv): moderately calcified, showing as a globose cavity covered by long and numerous simple setae (not illustrated).

\section{Supporting ossicles of the dorsal pyloric chamber (Figs $10,11)$}

Anterior mesopyloric ossicle (XIX): paired, moderately calcified, showing as an irregular plate, connection with pyloric ossicles: (III) and anterior pleuropyloric ossicle (XXXI). Posterior mesopyloric ossicle (XX): paired, firmly calcified and semi-oval shaped, connection with anterior pleuropyloric (XXXI) and uropyloric (XXI) ossicles.

Uropyloric ossicle (XXI): unpaired, firmly calcified, showing a wide arch in the middle and narrow in the extremities, connection with mesopyloric ossicle (XX).

Infra-uropyloric fragment (XXIa): paired, moderately calcified, showing as a small and large plate having accentuated central curvature, connection with posterior pleuropyloric ossicle (XXXIII).

\section{Supporting ossicles of the ventral pylorus and ampullae (Figs 10, 12)}

Preampullary ossicle (XXII): paired, moderately calcified, and showing a fine irregular plate, connection with ossicles of the cardio-pyloric valve (XVII), anterior inferior pyloric (XXIII), inferior ampullary (XXIV) and supra-ampullary (XXIX) ossicles. 


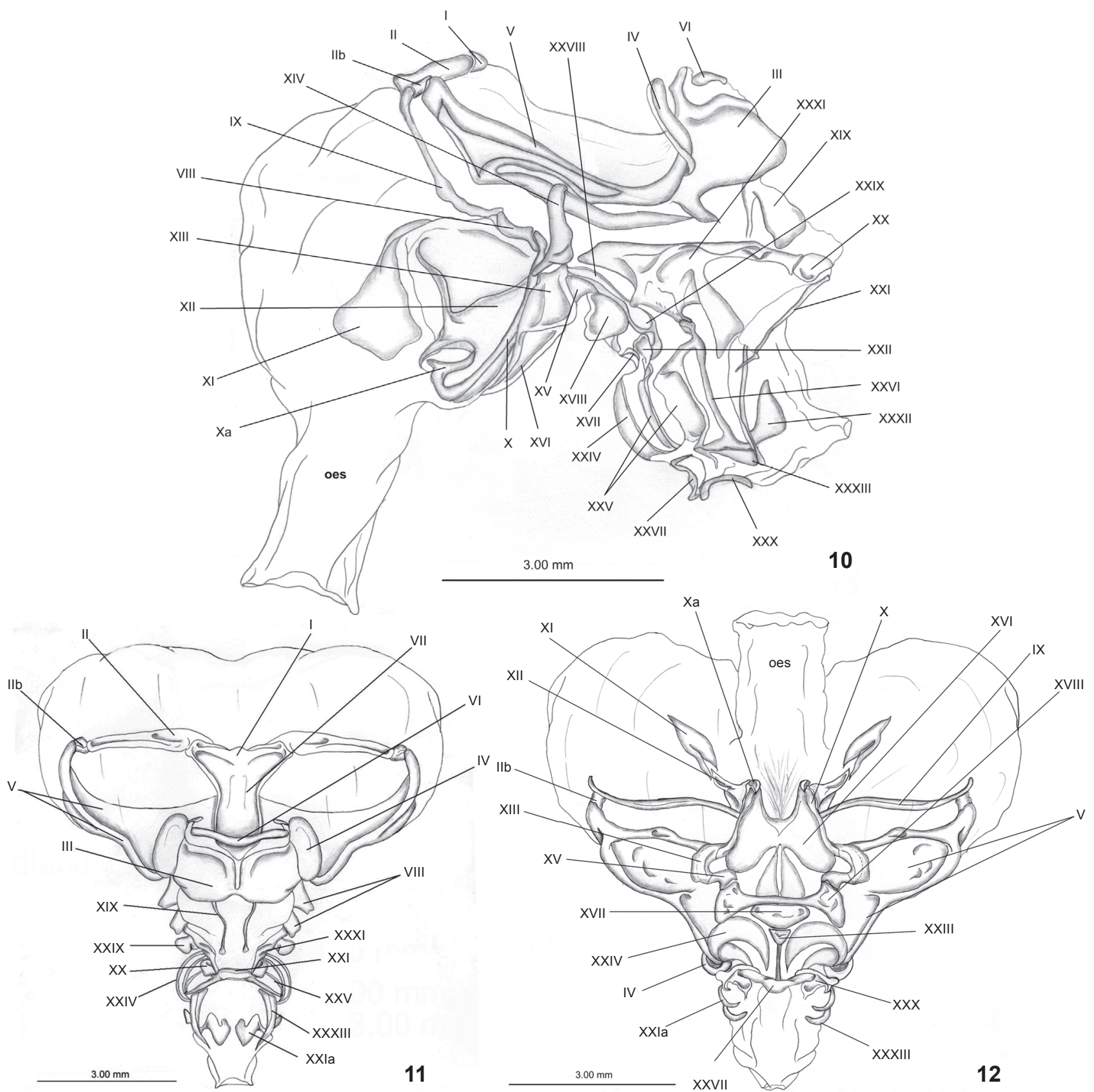

Figures 10-12. Dilocarcinus septemdentatus, cardiac and pyloric chambers of the foregut: (10) lateral view; (11) dorsal view; (12) ventral view. Mesocardiac ossicle (I), pterocardiac ossicle (II), postpterocardiac ossicle (IIb), pyloric ossicle (III), exopyloric ossicle (IV), zygocardiac ossicle $(\mathrm{V})$, propyloric ossicle $(\mathrm{VI})$, pectineal ossicle (VIII), prepectineal ossicle (IX), postpectineal ossicle (X), 'Quill' of the postpectineal ossicle (Xa), anterior lateral cardiac plate (XI), posterior lateral cardiac plate (XII), inferior lateral cardiac ossicle (XIII), subdentate ossicle $(\mathrm{XIV})$, lateral cardio-pyloric ossicle (XV), ossicle of the cardio-pyloric valve (XVI), anterior ossicle of the cardio-pyloric valve (XVI), posterior ossicle of the cardio-pyloric valve (XVII), lateral ossicle of the cardio-pyloric valve (XVIII), anterior mesopyloric ossicle (XIX), posterior mesopyloric ossicle $(X X)$, uropyloric ossicle $(X X I)$, preampullary ossicle (XXII), anterior inferior pyloric ossicle (XXIII), inferior ampullary ossicle (XXIV), ampullary roof ossicle, lower portion ossicle (XXV), ampullary roof ossicle, upper portion ossicle (XXVI), posterior inferior pyloric ossicle (XXVII), anterior supra-ampullary ossicle (XXVIII), middle supra-ampullary ossicle (XXIX), posterior supra-ampullary ossicle (XXX), anterior pleuropyloric ossicle (XXXI), middle pleuropyloric ossicle (XXXII), posterior pleuropyloric ossicle (XXXIII). 
Anterior inferior pyloric ossicle (XXIII): unpaired, moderately calcified and subtriangular, partially fused to a fine plate that it continues in the inferior ampullary ossicle (XXIV), connection in the superior extremity with the posterior ossicle of the cardio-pyloric valve (XVII) and in the inferior extremity with posterior inferior pyloric ossicle (XXVII), in the lateral portions linked for connection with the inferior ampullary ossicle (XXIV).

Inferior ampullary ossicle (XXIV): paired, moderately calcified, showing as a paired of fine convex plates, outer covered by fine transverse lines in which make protection of the filter press, connection with preampullary (XXII), anterior inferior pyloric (XXIII) and posterior inferior pyloric (XXVII) ossicles.

Ampullary roof ossicle, lower portion (XXV): paired, moderately calcified, showing as a fine plate, irregular shaped, disposed laterally, connection in the portion anterior with ampullary roof ossicle, upper portion (XXVI), posterior pleuropyloric ossicle (XXXIII) and through middle supra-ampullary ossicle (XXIX).

Ampullary roof ossicle, upper portion (XXVI): paired, strongly calcified, showing as a semi-rectangular and concave plate in the central area, fused to ampullary roof ossicle, lower portion (XXV), posterior pleuropyloric ossicle (XXXIII), firmly linked to anterior pleuropyloric (XXXI) and to posterior pleuropyloric (XXXIII) ossicles.

Posterior inferior pyloric ossicle (XXVII): unpaired, strongly calcified, irregular and concave, in the ventral view showing as a short stick and with extremities slightly curved upward, connection with anterior inferior pyloric (XXIII), posterior supraampullary (XXX) and inferior ampullary (XXIV) ossicles.

\section{Supra-ampullary supporting ossicles (Figs 10, 12)}

Anterior supra-ampullary ossicle (XXVIII): paired, moderately calcified, shown as a narrow plate, connection with the lateral cardio-pyloric ossicle (XV) and lateral ossicle of the cardio-pyloric valve, partially fused to the middle supra-ampullary ossicle (XXIX).,

Middle supra-ampullary ossicle (XXIX): paired, moderately calcified, showing as a small 1 plate, irregular and concave shaped, connection with preampullary (XXII), ampullary roof, lower portion (XXV) and fused to anterior supra-ampullary (XXVIII) ossicles.

Posterior supra-ampullary ossicle (XXX): paired, strongly calcified, showing as plates with anterior portion fine and narrow in the central direction, connection with the terminal portion of posterior inferior pyloric (XXVII) and posterior pleuropyloric (XXXIII) ossicles.

\section{Supporting ossicles of the lateral pylorus (Figs 10,11)}

Anterior pleuropyloric ossicle (XXXI): paired, strongly calcified, showing as elongated and curved bars, connection with posterior mesopyloric ossicle (XX), ampullary roof ossicle, upper portion (XXVI), anterior supra-ampullary ossicle (XXVIII) and middle pleuropyloric ossicle (XXXII).
Middle pleuropyloric ossicle (XXXII): paired, moderately calcified, subtriangular plate-shaped, connection with ossicles of the superior ampullary roof ossicle, upper portion (XXVI).

Posterior pleuropyloric ossicle (XXXIII): paired, strongly calcified, irregular, long and slightly curved, firmly linked to ampullary roof ossicle, lower portion (XXV), to ossicle of the ampullary-roof ossicle, upper portion (XXVI), infra-uropyloric fragment (XXIa) and posterior supra-ampullary ossicle (XXX).

\section{DISCUSSION}

The gross morphology of the gastric mill of the freshwater crabs analyzed in this study is quite complex. Its structural organization is well-developed and features the specialized brachyuran food trituration mechanism. According to DALL \& Moriarty (1983), this complex foregut may be linked to macrophagy and predation, being associated with the ingestion of larger food particles. The functional morphology of the foreguts was extensively investigated for other brachyurans by FACtor (1982), Abrunhosa et al. (2003) and CecCaldi (1989). In addition to the contribution of these studies to the knowledge of the biology of those respective taxa, the results are especially important for the successful culture of the economically interesting species.

To understand the function of the decapod foreguts, a correct preparation of ossicle structures is of primary importance; this includes the application of specific methods such as staining and an adequate agent for tissue removal that does not damage the ossicles. BrösIng et al. (2002), describing the ossicle system of the foregut of three species of Dromiidae, demonstrated a new coloration method that allowed the identification of five ossicles that had not been recognized in previous descriptions of the same species by Nauck (1880) and Patwardhan (1934): pterocardiac, postpterocardiac, lateral mesopyloric, posterior uropyloric and the anterior process of the ampullary roof ossicle, upper portion. The method of Brösing et al. (2002) was used in the preparation of the four foreguts described here, making it possible to detect the presence of the postpterocardiac, lateral mesopyloric and posterior uropyloric ossicles.

In general, the foreguts of $F$. reflexifrons, $S$. pictus, $V$. serrata and $D$. septemdentatus are apparently similar to those described for brachyuran Libinia emarginata, Uca sp. and Calappa sulcata Rathbun, 1898 by MeIss \& Norman (1977). They show similarities mainly in the degree of calcification, size and number of ossicles. On the other hand, all of these foreguts are quite different morphologically when compared to those of shrimps described previously, e.g. Farfantepenaeus dourarum (Burkenroad, 1938) and F. aztecus (Ivens, 1891) (MeIss \& Norman 1977), Litopenaeus vannamei (Boone, 1931) (Abrunhosa \& Melo 2008), palaemonid Macrobrachium rosembergii (De Man, 1870) (Abrunhosa \& Melo 2002) and for spiny lobster species Jasus edwardsii (Hutton, 1875) (Nishida et al. 1990).

Similarities related to the pattern and presence of gastric mill ossicles were found between the brachyurans of the present 
study and juveniles of the anomuran Aegla platensis Scmitt, 1942 by (CASTRO \& BOND-BuCKup 2003), as well as juveniles of king crab Paralithodes camtschaticus (Tilesius, 1815), P. brevipes (H. Milne Edwards \& Lucas, 1841) and P. platypus Blandt, 1850 (AвRUNHosa \& KitTAKa 1997), which differed only in their smaller number of ossicles. Few studies, however, are related to the description of the foreguts of freshwater crabs. MARTIN et al. (1998) carried out a descriptive and comparative study of the main ossicles of Austinograea williamsi Hessler \& Martin, 1879 but, unfortunately, the authors did not provide a complete description. In another study, the morphological description of a freshwater decapod related to the genus Aegla Leach, 1820 (Anomura) was described by CASTRo \& Bond-Buckup (2003). These authors recorded 22 ossicles and noticed the presence of paired of oesophageal valves and thorns in the anterior margin of the zygocardiac $(\mathrm{V})$, characteristics not observed in any other species considered here. The authors presume that the function of the spines observed in the zygocardiac possibly may increase the capacity for triturating food particles.

The differences found in the foregut structures of the four species studied here support the hypothesis of MeIss \& NoRman (1977) that variations among the foreguts are better noticed when paying special attention to presence/absence of ossicles and to ossicle fusion. Slight, but relevant, morphological differences were observed among the freshwater crab species studied (Tab. I). In $S$. pictus and $V$. serrata, the small and elongated oesophagus was observed connected to the ventral portion of the cardiac chamber; in D. septemdentatus and $F$. reflexifrons, this structure is of intermediate size, and is connected to the anteroventral area of the cardiac chamber. The latter two species further differed from the others by showing a comparatively wide cardiac sac (Fig. 1). Other differences, regard the number of observed ossicles, with a total of 38 ossicles for $S$. pictus and V. serrata, but 37 ossicles for $D$. septemdentatus and $F$. reflexifrons.

Other distinct differences among the three species were related to absence/presence and morphological features of the ossicles. These differences may be used for discriminating morphologically similar species. For instance, the absence of the fragment infra-uropyloric is only observed in the pseudothelphusid, F. reflexifrons. Also, the zygocardiac (V) ossicle presented 17 denticles in F. reflexifrons, as opposed to the 7-9 denticles found in the three studied trichodactylids.

Differences were also found among the three trichodactylids $D$. septemdentatus, $V$. serrata and $S$. pictus. The latter species differed with respect to the form of the anterior mesopyloric ossicle (XIX), which resembled a concave and narrow plate, whereas it was a convex, wide plate in $V$. serrata, and in $D$. septemdentatus the same ossicle was narrow and long. The zygocardiac (V) ossicle of S. pictus and D. septemdentatus presented 7 protuberant denticles (constituting the lateral tooth), in contrast with with nine denticles in $V$. serrata. Notable characteristics were observed in the pectineal (VIII) ossicle for $V$. serrata in which, this ossicle lacked teeth and bear numerous long setae. The species also diverged in the connection type established by the anterior lateral cardiac plate (XI) that is only partially fused to the posterior lateral cardiac plate (II) in S. pictus, whereas this structure is linked through a firm connection in $V$. serrata.

According to Castro \& Bond-Buckup (2003), the presence or absence of certain ossicles in the anomuran A. platensis may be related to fusion between ossicles separated in other species. Despite resulting in a lesser total number of ossicles, the foregut of A. platensis is still complex and suitable to macrophagy and predation, as in the species of the present study.

Meiss \& Norman (1977) reported that decapod species with a complex gastric mill typically bear a small mesocardiac ossicle, a well-developed pyloric ossicle and long urocardiac and zygocardiac ossicles, corresponding structures could be confirmed for the gastric mills of F. reflexifrons, $S$. pictus, $V$. serrata and $D$. septemdentatus.

Differences regarding the degree of calcification of the gastric ossicles of the species investigated here were small. However, the pterocardiac ossicle of $V$. serrata appeared only moderately calcified while it was firmly calcified in the other species.

The uropyloric ossicle (XXI) was firmly calcified in $V$. serrata and D. septemdentatus, however, in F. reflexifrons and $S$. pictus it showed a moderate calcification. The structural pattern of this ossicle also varied, resembling a fine arch $V$. serrata and $S$. pictus while it was more robust in its central section and tapering towards the extremities in D. septemdentatus; in $F$. reflexifrons, it was plate-like with bent extremities.

Differences were observed in the connection type of the ampullary roof, lower portion (XXV), ampullary roof ossicle, upper portion (XXVI) and posterior inferior pyloric ossicle (XXVII). The first is fused to the ampullary roof ossicle, upper portion (XXVI) and to the posterior pleuropyloric (XXXIII) in the species $F$. reflexifrons and $V$. serrata. In the latter species, no connection to the posterior pleuropyloric ossicle (XXXIII) was observed but there was a solid connection to the posterior supra-ampullary ossicle (XXX). However, in $S$. pictus and $D$. septemdentatus this ossicle showed a firm connection to the ampullary roof-superior portion (XXVI) and to the posterior pleuropyloric (XXXIII).

In the ampullary roof ossicles, the upper portion (XXVI) was fused to the posterior pleuropyloric ossicle (XXXIII) in $F$. reflexifrons and $D$. septemdentatus, whereas a solid connection was observed in $S$. pictus and $V$. serrata. In F. reflexifrons, the posterior inferior pyloric ossicle (XXVII) was partially fused to the posterior supra ampullary ossicle (XXX), while it showed a firm connection in the other species. A difference was observed in the species $D$. septemdentatus, regarding the connection type of anterior supra-ampullary ossicle (XXVIII) to the middle supra-ampullary ossicle (XXIX), in which they were locally fused, whereas in the other species, a firm connection of these ossicles were observed. 
The structure of the anterior pleuropyloric ossicle (XXIX) also varied among species. This ossicle had the form of an irregular plate with re-entrance in the anterior margin in $F$. reflexifrons, a narrow and irregular plate in S. pictus; it was short and little enlarged in $V$. serrata and consisted of a small, rounded and concave plate in D. septemdentatus.

Detailed descriptions of all ossicles may be useful for discriminating morphologically similar species, as exemplified by those of the genus Valdivia, where difficulties in the identification of some species arise due to changes in the external morphology during growth, misidentification led in consequence to much confusion in taxonomic treatments of this group, including multiple descriptions of the same species under different synonyms (MAGALHÃEs 2003). We hope that the morphological analyses presented here will be useful also to the taxonomist and will possibly help to avoid a similar situation with the genera in question.

\section{LITERATURE CITED}

Abrunhosa, F.A. \& J. Kittaka. 1997. Functional morphology of mouthparts and foregut of the last zoea, glaucothoe and first juvenile of the king crabs Paralithodes camtschaticus, $P$. brevipes and P. platypus. Fisheries Sciences 63 (6): 923-930.

Abrunhosa, F.A. \& M.A. Melo. 2002. Morfologia comparativa do primeiro e último estágios zoea e juvenil de Macrobrachium rosembergii (De Man, 1879). Revista Ciência Agronômica 33 (2): 65-68.

Abrunhosa, F.A.; M.A. Melo \& J.P. Abrunhosa. 2003. Development and functional morphology of the foregut of larvae and postlarva of Ucides cordatus (Decapoda, Ocypodidae). Nauplius 11 (1): 37-43.

Abrunhosa, F.A \& M.A. Melo. 2008. Development and functional morphology of the foreguts of larvae and postlarvae of three crustacean decapods. Brazilian Journal of Biology 68: 631637.

Brösing, A. S. Richter \& G. Scholtz. 2002. The foregut-ossicle system of Dromia wilsoni, Dromia personata and Lauridromia intermedia studied with a new staining method. Arthropod Structure and Development 30: 329-338.

Castro, T.S. \& G. Bond-Buckup. 2003. The morphology of cardiac and pyloric foregut of Aegla platensis Schmitt (Crustacea: Anomura: Aeglidae). Memoirs of Museum Victoria 60: 53-57.

CecCALDI, H.J. 1989. Anatomy and physiology of digestive tract of crustacean decapods reared in aquaculture. Advances in Tropical Aquaculture 9: 243-259.

DALL, W. \& D.J.W. MoRIARTY. 1983. Functional aspects of nutrition and digestion, p. 215-261. In: L.H. MANTEL (Ed.). The biology of Crustacea: internal anatomy and physiological regulation. New York, Academic Press, 383p.

FACTOR, J.R. 1982. Development and Metamorphosis of the Feeding Apparatus of the Stone Crab, Menippe mercenaria (Brachyura, Xanthidae). Journal of Morphology 172: 299-312.
Jha, A. \& S. Homechaudhuri. 2001. Understanding the gastric mill structure of a macrophagous shrimp Metapenaeus monoceros (Fabricius). Current Science 80 (5): 620-622.

Kunze, J. \& D.T. Anderson. 1979. Functional morphology of the mouthparts and gastric mill in the hermit crabs Clibanarius taeniatus (Milne-Edwards), Clibanarius virescens (Krauss), Paguristes squamosus McCulloch and Dardanus setifer (MilneEdwards) (Anomura: Paguridae). Australian Journal of Marine and Freshwater Research 30: 683-722.

Martin, J. W.; P. Jourharzadeh \& P.H. Fitterer. 1998. Description and comparison of major foregut ossicles in hydrothermal vent crabs. Marine Biology 131: 259-1998.

Magalhães, C. 2003. Famílias Pseudothelphusidae e Trichodactylidae, p. 143-287. In: G.A.S. Melo. (Org.). Manual de identificação dos crustáceos decápodos de água doce do Brasil. São Paulo, Edições Plêiade, 426p.

Meiss, D.E. \& R.S. Norman. 1977. Comparative study of the stomatogastric system of several decapod Crustacea. Journal of Morphology 152: 21-54.

Melo, G.A.S. 2003. Manual de identificação dos Crustacea Decapoda de água doce do Brasil. São Paulo, Plêiade, 429p.

Mikami, S. \& F. TaKashima. 1993. Development of the proventriculus in larvae of the slipper lobster, Ibacus ciliatus (Decapoda, Scyllaridae). Aquaculture 116: 199-217.

NAUCK, E. 1880. Das Kaugerüst der Brachyura. Zeitschrift für wissenschaftliche Zoologie. 34: 1-69.

Nishida, S.; B.D. Quigley; J.D. Booth; T. Nemoto \& J. Kittaka. 1990. Comparative morphology of the mouthparts and foregut of the final stage phyllosoma, puerulus, and postpuerulus of the rock lobster Jasus edwardsii (Decapoda: Palinuridae). Journal of Crustacean Biology 10 (2): 293-305.

Patwardhan, S.S. 1934. On the structure and mechanism of the gastric mill in Decapoda. I. The structure of the gastric mill in Parathelphusa guerini (Milne Edwards). Proceedings of the Indian Academy of Science B 1: 183-196.

Pilgrim, R.L. 1964. Observations on the anatomy of Squilla mantis Latreille (Crustacea, Stomatopoda). Publi-cazioni della Stazione Zoologica di Napoli 34: 9-42.

Pilgrim, R.L.C. 1965. Some features in the morphology of Lomis hirta (Lamarck) (Crustacea: Decapoda) and a discussion of its systematic position and phylogeny. Australian Journal of Zoology 13: 545-557.

Pilgrim, R.L. 1973. Axial skeleton and musculature in the thorax of the hermit crab Pagurus bernhardus (Anomura, Paguridae). Journal of the Marine Biological Association of the United Kingdom 53: 363-396.

Pinn E.H.; L.A. Nickell; A. Rogerson \& R.J.A. Atrinson. 1999. Comparison of gut morphology and gut microflora of seven species of mud shrimp (Crustacea: Decapoda: Thalassinidea). Marine Biology 133: 103-114.

Rodriguez, G. 1981. Decapoda, p. 41-50. In: S.H. HurlberT; G. Rodríguez \& N.D. SANTOS (Eds). Aquatic biota of tropical south América. San Diego, University Press, 298p. 
Rodriguez, G. \& C. MagalHÃes. 2005. Recent advances in the biology of the neotropical freshwater crab family Pseudothelphusidae (Crustacea, Decapoda, Brachyura). Revista Brasileira de Zoologia 22 (2): 354-365.

Skilleter, G.A. \& D.T. Anderson. 1986. Functional morphology of the chelipeds, mouthparts and gastric mill of Ozius truncates (Milne Edwards) (Xanthidae) and Leptograpsus variegatus (Fabricius) (Grapsidae) (Brachyura). Australian Journal of Marine and Freshwater Research 37: 67-79.

SUTHERS, I.M. 1984. Functional morphology of the mouthparts and gastric mill in Penaeus plebejus Hess (Decapoda: Penaeidea). Australian Journal of Marine and Freshwater Research 35: 785-792.

Suthers, I.M. \& D.T. Anderson. 1981. Functional morphology of mouthparts and gastric mill of Ibacus peronii (Leach) (Palinura: Scyllaridae). Australian Journal of Marine and Freshwater Research 32: 931-944.

Yeo, D.C.J.; P.K.L. NG; N. Cumberlidge; C. Magalhães; S.R. Daniels.\& M.R. CAmpus. 2008. Global diversity of crabs (Crustacea: Decapoda: Brachyura) in freshwater. Hydrobiologia 595: 275-286.

Submitted: 07.VII.2009; Accepted: 25.III.2010.

Editorial responsibility: Marcos D.S. Tavares 